\title{
Evaluation of Dental Enamel Mass in Prolonged Supervised Dental Bleaching Protocol with Calcium-Containing Gel
}

\author{
Evaluación de la Masa de Esmalte Dental Expuesto a Protocolo de \\ Blanqueamiento Dental Supervisado Prolongado con Gel Conteniendo Calcio
}

Heitor Sales de Barros Santos'; Mara Eliane Soares Ribeiro; Taíse Sousa Pamplona da Silva; Rafael Rodrigues Lima ${ }^{2}$; Sandro Cordeiro Loretto ${ }^{1}$ \& Mário Honorato da Silva e Souza Júnior ${ }^{1}$

SANTOS, H. S. B.; RIBEIRO, M. E. S.; DA SILVA, T. S. P.; LIMA, R. R.; LORETTO, S. C. \& DA SILVA E SOUZA JÚNIOR, M. H. Evaluation of dental enamel mass in prolonged supervised dental bleaching protocol with calciumcontaining gel. Int. J. Odontostomat., 15(2):415-4120, 2021.

ABSTRACT: The objective of this study was to determine the enamel mass variation after a prolonged bleaching treatment using a calcium-containing $4 \%$ hydrogen peroxide gel Twenty sound bovine incisors were randomly assigned to two groups ( $n=10)$ stored in G1) distilled water and G2) artificial saliva. An electronic analytic scale (.000 grams measurements) was used to determine the enamel mass variation before and after the bleaching procedures at the following evaluation times: T0) before the bleaching procedures; T1) 14 days of treatment, as instructed by the manufacturer; T2) 21 days of treatment, $50 \%$ beyond what is instructed by the manufacturer; and T3) 28 days of treatment, $100 \%$ beyond what is instructed by the manufacturer. The highest mean was observed at T2/G2 $(0.3259 \mathrm{~g})$ and the lowest at T2/G1 (0.3265 g). The specimens stored in distilled water (G1) showed $6 \%$ mass reduction when T0 $(0.3277 \mathrm{~g})$ was compared to T3 $(0.3277 \mathrm{~g})$. On the other hand, the specimens stored in artificial saliva exhibited a significant mass increase of $19 \%$ when T0 $(0.3521 \mathrm{~g})$ was compared to T3 $(0.3528 \mathrm{~g})$. Prolonged bleaching therapy using $4 \%$ hydrogen peroxide with calcium resulted in a massive reduction when water was used as a storage medium. When the specimens were stored in artificial saliva, an increase in mass was observed, probably due to the mineralizing properties of the artificial saliva.

KEY WORDS Dental bleaching; dental enamel; peroxides.

\section{INTRODUCTION}

With the decline in the occurrence of dental caries, the demand for dental services has been gradually changed with a greater demand in relation to aesthetic procedures (Spear \& Kokich, 2007; Mehl et al., 2011). In this context, one of the most requested procedures is dental bleaching (Cakir et al., 2011; Borges et al., 2015; Aka \& Celik, 2017). This, when performed by the at-home technique, recommends the use of a low concentration of the bleaching agent (10 to $22 \%$ carbamide peroxide or hydrogen peroxide of 3.5 to 10 $\%)$ for a longer period, when compared to the technique performed in the office (Alqahtani, 2014; Meireles et al., 2012; Vilhena et al., 2019). At home bleaching has some advantages over in-office treatment, including easy application, low cost, low post-operative sensitivity, less irritation to gingival tissue, and high success rates (Sulieman, 2005; Cakir et al.; Alqahtani).

Patients undergoing treatment in this modality are also directly responsible for the success of the technique (Baia et al., 2020), once they have the material for daily use and, depending on the concentration and formula (carbamide peroxide or hydrogen), this time can vary from 30 minutes to 8 hours daily (Peruchi et al., 2011). In the expectation of wanting whiter teeth, it is not uncommon for the patient to extend the recommended time, leading to unwanted consequences, such as increased sensitivity (Peruchi et al.). In addition,

\footnotetext{
${ }^{1}$ Dental Materials Laboratory of the Postgraduate Program in Dentistry, Institute of Health Sciences, Federal University of Pará, Belém, PA, Brazil. ${ }^{2}$ Laboratory of Functional and Structural Biology, Institute of Biological Sciences, Federal University of Pará, Belém, PA, Brazil.
}

Received: 2019-07-28 Accepted: 2020-11-12 
damage to mineralized dental structures, increased roughness (Abouassi et al., 2011), reduced microhardness (Mondelli et al., 2015), and changes in mineral content, even when the manufacturer's instructions are followed may arise (Cakir et al.; Souza et al., 2010).

In an attempt to minimize the reactions of transient losses of minerals of the hard dental tissues, calcium was added to the formulations of bleaching gels, promoting the maintenance of calcium values at adequate levels in enamel, without, interfering in the color provided by the bleaching treatment (Cavalli et al., 2011; Borges et al.; Santos et al., 2019).

Thus, in view of the limitation of scientific evidence of prolonged use of hydrogen peroxide in $4 \%$, with the addition of calcium in its formulation, the objective of this in vitro study is to evaluate the variation of enamel mass under prolonged dental bleaching protocols.

\section{MATERIAL AND METHOD}

This research began after the Federal University of Pará Animal Use Ethics Committee (CEUA) approved the final project (register no. 3382190117). Twenty fully erupted and sound bovine incisors of the Bos Taurus Indicus species (mean age 24 months) were collected from a slaughterhouse (SOCIPE), which is acquainted with the requirements of teeth extraction for dental researches.

After teeth disinfection in a $0.1 \%$ tymol solution (A Formula, Belém, Pará, BR), all periodontal debris were removed by scaling and the surfaces pumiced. Next, a careful examination under a stereomicroscope $(40 \mathrm{X})$ was carried out to detect enamel cracks and fractures. In these cases, the teeth were discarded. Eventually, the teeth were stored in distilled water $\left(4^{\circ} \mathrm{C}\right)$ for no longer than six months until testing.
Enamel blocks were obtained from the central part of the crowns using a double-sided diamond disc (KG Sorensen, Cotia, São Paulo, BR) and a digital caliper (DIN 862; Mitutoyo, São Paulo, BR). The residual dentine structure was removed using a no. 4138 diamond bur (KG Sorensen, Cotia, SP, BR). All cutting procedures were performed under massive water irrigation. Finally, blocks of enamel with approximately $10 \mathrm{~mm} \times 8 \mathrm{~mm}$ of similar weight were impressed.

The enamel blocks were immersed in an ultrasonic tub with distilled water for 20 minutes, before setting in PVC rings with impression condensation silicone (Coltene, Bonsucesso, RJ, $B R)$. The specimens were then randomly assigned to two groups $(n=10)$ according to the experimental storage medium: G1- distilled water and G2- artificial saliva.

Before bleaching, acetate frames were individually built up to standardize the volume of gel applied on the dental surfaces. White Class $4 \%$ (Calcium-containing $4 \%$ hydrogen peroxide) was used in association with artificial saliva (Table I). Thus, a disposable plastic syringe was used to apply 0.1 $\mathrm{mL}$ of bleaching gel and $0.05 \mathrm{~mL}$ of artificial saliva on the enamel surfaces before setting the acetate frames. During the bleaching procedures, the specimens were put in a filled plastic box and placed in a biological oven at $37^{\circ} \mathrm{C}$ for two hours. At the end of the bleaching time, the specimens were washed with water and air sprayed for one minute, and the water content was removed using a drier (Philco Titanium Travel, Joinvile Santa Catarina, BR) for two minutes (Almeida et al., 2019). This drying time was previously determined in the pilot study, as subsequently no weight changes were observed. These procedures were repeated for 28 days.

After drying the specimens, as already described, they were weighted on an electronic

Table I. Description of the materials used in the experiment, along with their trade names, manufacturers, and composition.

\begin{tabular}{lll}
\hline Material & \multicolumn{1}{c}{ Manufacturer } & \multicolumn{1}{c}{ Composition } \\
\hline $\begin{array}{l}\text { White Class } \\
\text { bleaching gel }\end{array}$ & $\begin{array}{l}\text { FGM Produtos } \\
\text { Odontológicos Ltda, } \\
\text { Joinville, Santa } \\
\text { Catarina, Brazil }\end{array}$ & $\begin{array}{l}4 \% \text { hydrogen peroxide, neutralized Carbopol, potassium nitrate, sodium } \\
\text { fluoride, calcium gluconate, stabilizer, wetting, deionized Water. }\end{array}$ \\
$\begin{array}{l}\text { Artificial human } \\
\text { saliva }\end{array}$ & $\begin{array}{l}\text { A fórmula - Farmácia } \\
\text { de Manipulação, } \\
\text { Belém, Pará, Brazil }\end{array}$ & $\begin{array}{l}\text { Sodium bicabornate 2190 mg, potassium phosphate 1270 mg, magnesium } \\
\text { chloride 125 mg, calcium chloride 441 mg, potassium chloride } 820 \mathrm{mg}, \\
\text { sodium fluoride 4.5 mg, nipazole 100 mg, sorbitol 24 mg, } \\
\text { carboxyme thylcellulose } 8 \mathrm{mg}, \text { and distilled water } 3000 \mathrm{ml}(\mathrm{pH}=7) .\end{array}$ \\
\hline
\end{tabular}


SANTOS, H. S. B.; RIBEIRO, M. E. S.; DA SILVA, T. S. P.; LIMA, R. R.; LORETTO, S. C. \& DA SILVA E SOUZA JÚNIOR, M. H. Evaluation of dental enamel mass in prolonged supervised dental bleaching protocol with calcium-containing gel. Int. J. Odontostomat., 15(2):415-4120, 2021.

analytic balance (Quimis-AS 210, Diadema-São Paulo, BR) with $0.0001 \mathrm{~g}$ accuracy (Zimmer et al., 2015). These values were recorded as T0. After 14 days/two hour per day bleaching, as instructed by the manufacturer, the specimens were washed, dried, and weighted; the data were recorded as T1; and the same procedures were repeated at 21 days, corresponding to a $50 \%$ addition to the recommended time (T2), and 28 days, at a $100 \%$ addition (T3). After each bleaching treatment, the specimens were placed in a biological oven at $370 \mathrm{C}$ in their corresponding media: distilled water (G1) or artificial saliva (G2).

The Shapiro-Wilk test detected normal distribution, and thus ANOVA for repeated measurements with Tukey post test was applied to the data $(p \leq 0.05)$.

\section{RESULTS}

The highest mean was observed for G2/T2 (artificial saliva/21 days) $(0.3529 \mathrm{~g})$ and the lowest for $\mathrm{G} 1 / \mathrm{T} 2$ (distilled water/21 days) $(0.3265 \mathrm{~g})$. When the data were analyzed in $\mathrm{G} 1$, a $6 \%$ reduction in mass was observed up to 28 days of bleaching (TO -0.3277 $\mathrm{g} / \mathrm{T} 3-0.3271 \mathrm{~g})(\mathrm{p} \geq 0.05)$. On the other hand, in $\mathrm{G} 2$, a $19 \%$ increase in mass was detected when T0 (0.3521) was compared to T3 (0.3528), which was statistically significant $(p \leq 0.05)$.

When times were individually compared, there were significant differences between $\mathrm{T} 0$ and $\mathrm{T} 2$ for $\mathrm{G} 1$ $(p=0.0268)$ and T2 and T3 $(p=0.0019)$. For $G 2$, the differences were observed when T0 was compared to T1 $(p=0.0042)$, T0 to T2 $(p=0.0003)$, T0 to T3 $(p=0.0005)$, and T1 to T2 $(p=0.0082)$. The values and comparisons are presented in Table II.

Table II. Difference between mean (and standard deviation) of the mass variation of G1 and G2, in grams (g), of dental enamel at times $0,14,21$, and 28. ANOVA for repeated measurements, adopting level a of significance $(p \leq 0.05)$.

\begin{tabular}{ccccc}
\hline Groups/ & \multicolumn{4}{c}{ Times Treatment } \\
\hline & T0 & T1 & T2 & T3 \\
\hline G1 & $0.3273( \pm 0.064)^{\mathrm{A}}$ & $0.3273( \pm 0.064)^{\mathrm{A}}$ & $0.3265( \pm 0.063)^{\mathrm{B}}$ & $0.3271( \pm 0.064)^{\mathrm{A}, \mathrm{B}}$ \\
$\mathrm{G} 2$ & $0.3521( \pm 0.090)^{\mathrm{a}}$ & $0.3526( \pm 0.091)^{\mathrm{b}}$ & $0.3529( \pm 0.091)^{\mathrm{C}}$ & $0.3528( \pm 0.091)^{\mathrm{d}, \mathrm{b}, \mathrm{c}}$ \\
\hline
\end{tabular}

* Different letters indicate statistical difference at $5 \%$ in the intragroup.

\section{DISCUSSION}

The bleaching treatment as proposed in this in vitro study using Calcium-containing $4 \%$ hydrogen peroxide was able to produce mass variation in the enamel blocks, regardless of the storage medium. The specimens that were stored in distilled water (G1) showed a mass reduction of $6 \%$ when no treatment, T0 (0.3277 g), was compared to 28-day treatment, T3 $(0.3271 \mathrm{~g})(\mathrm{p} \leq 0.05)$. On the other hand, when the specimens were stored in artificial saliva (G2), the mass variation was positive, that is, an increase of $19 \%$ was observed when T0 $(0.3521 \mathrm{~g})$ was compared to T3 $(0.3528 \mathrm{~g})(\mathrm{p} \leq 0.05)$.

The bleaching mechanism of action is still not totally elucidated; however, the more proposed theory reports that the main mechanism takes place through an oxidizing process in which the hydrogen peroxide goes deep into the enamel and dentin structures (Alqahtani). Hydrogen peroxide is an oxidizing agent that is able to produce free radicals $(\mathrm{H} 2 \mathrm{O}+\mathrm{O} 2)$, which are very reactive. In a purely aqueous state, the hydrogen peroxide is slightly acidic. The result is perhydroxyl ( $\mathrm{HO} 2)$, which is the most potent free radical. To be able to promote the formation of the ion perhydroxyl, hydrogen peroxide needs to become alkaline; the optimum $\mathrm{pH}$ for this to occur is 9.5 to 10 (Sun et al., 2011).

Ideally, the bleaching mechanism should be limited to the pigments, which are basically organic structures. However, it is important to remember that the enamel and dentin structures have organic compounds susceptible to free-radical action (Kwon \& Wertz, 2015). The bleaching gels can change the enamel micromorphology, such as by causing depressions followed by an increase in surface roughness, which is related to the oxidizing process followed by organic material breakdown (Abouassi et al.; Mahringer et al., 2009; Kwon \& Wertz). One may conclude that this scenario led to an irreversible partial 
inorganic collapse in G1 and may explain the significant reduction in mass observed.

Another important issue to be addressed is the initial $\mathrm{pH}$ of the bleaching gels. Acidic $\mathrm{pHs}$ are responsible for an increase in roughness to a greater extent when compared to the gel concentration ( $\mathrm{Xu}$ et al., 2011). Peroxides are normally stored in a slightly acidic $\mathrm{pH}$, which prevents spontaneous breakdown and free radical release (Sun et al., 2011; $\mathrm{Xu}$ et $\mathrm{al}$.). The contact with saliva, which can raise the $\mathrm{pH}$, and the mouth temperature are responsible for inducing the free radical release. As informed by the manufacturer of the product used in this study, the initial $\mathrm{pH}$ of the gel is neutral. Therefore, based on this information, one cannot support that the gel $\mathrm{pH}$ may have influenced the mass reduction in the first moments when the gel met the enamel surfaces. Thus, the main action that caused mass reduction was the attack on the organic compounds in the enamel structure.

Some studies have demonstrated that the addition of mineralizing agents, such as sodium fluoride, ATP, and calcium, in the gel formulations may reduce the demineralization caused by the bleaching therapy (Chen et al., 2008; Alexandrino et al., 2014). The gel used in this study has calcium and sodium fluoride added to $4 \%$ hydrogen peroxide. Even so, when the specimens were stored in distilled water, these mineralizing compounds were not able to replace the eventual mineral loss in the 21-day bleaching therapy. However, in the 28day treatment, an increase in mass was detected. One possible explanation is that after such a long period, the mineralizing agents in the gel were able to compensate for the mass loss.

When microhardness was studied, the use of gels containing calcium showed lower microhardness loss (Pizani et al., 2015). However, when surface roughness was observed, the use of gels containing mineralizing agents, such as calcium, led to the increase in roughness (Sasaki et al., 2015). The explanation of these results is the deposition of mineralizing agents and their by-products on the bleached enamel surfaces. When distilled water was used as a storage medium, this mineralization action may have occurred slowly, so the results in mass increase were only detected in the 28-day treatment. It is known that human saliva is rich in proteins, calcium, phosphate and fluorine and these components have a remineralizing effect, being incorporated into the enamel surface (Heshmat et al., 2016).

When a mineralization capacity of different artificial salives was studied in an environment with erosive problems, all formulations were considered positive, or that were not observed in the distilled water storage medium (Ionta et al., 2014). In addition, a study carried out to verify the influence of prolonged tooth bleaching with $10 \%$ carbamide peroxide in different storage media, concluded that the specimens stored in artificial saliva undergo an increase in mass. However the specimens used in distilled water suffered a decrease in mass (Ribeiro et al., 2019). Corroborating our findings, where the specimens stored in artificial saliva had a progressive mass gain, or which may have occurred due to the incorporation of saliva components and remineralizing agents of the gel bleach on the surface of the specimens.

It should be emphasized that the aim of this in vitro study was to assess the effects of bleaching treatments using mineralizing gel and the storage medium on the mass variation of enamel. Although there was no comparison group using a bleaching gel without a mineralizing agent, the specimens bleached up to day 28 were the same since they were first weighted (T0), that is, there were self-controls within groups.

Another issue that needs to be addressed is the amount of mass variation, which can be considered clinically insignificant when the absolute values are considered. The permanent loss of enamel, such as after orthodontic bracket debonding and residual adhesive detachment (Fjeld \& Øgaard, 2006), is probably more harmful than a transient mass loss due to bleaching procedures.

It is also known that certain habits, such as the consumption of some beverages and fruit juices that are acidic in nature, are much more damaging to the dental structure (Franklin et al., 2014; Zimmer et al.). Orange juice, for example, is able to reduce the microhardness of the enamel and significantly modify its superficial topography. As a result, a fragile and rougher surface forms, allowing the development of caries and noncarious lesions (Ren et al., 2009). In this perspective, it was also demonstrated that the amount of dental calcium lost after 12 hours of bleaching treatment was similar to the amount lost when the dental structure (or enamel) was exposed to an acidic beverage or citric juices for a few minutes (Grobler et al., 2009). 
SANTOS, H. S. B.; RIBEIRO, M. E. S.; DA SILVA, T. S. P.; LIMA, R. R.; LORETTO, S. C. \& DA SILVA E SOUZA JÚNIOR, M. H. Evaluation of dental enamel mass in prolonged supervised dental bleaching protocol with calcium-containing gel. Int. J. Odontostomat., 15(2):415-4120, 2021.

\section{CONCLUSION}

According to the experimental design of this study, it was possible to conclude that long-time bleaching therapy, using Calcium-containing $4 \%$ hydrogen peroxide, was able to alter the mass of dental enamel independent of the storage medium used. In relation to $\mathrm{G} 2$ (stored in artificial human saliva), the results obtained demonstrated the remineralizing potential of saliva.

SANTOS, H. S. B.; RIBEIRO, M. E. S.; DA SILVA, T. S. P.; LIMA, R. R.; LORETTO, S. C. \& DA SILVA E SOUZA JÚNIOR, M. H. Evaluación de la masa de esmalte dental expuesto a protocolo de blanqueamiento dental supervisado prolongado con gel conteniendo calcio. Int. J. Odontostomat., 15(2):415-420, 2021.

RESUMEN: El objetivo de este estudio fue determinar la variación de la masa del esmalte después de un tratamiento de blanqueamiento prolongado utilizando calcio conteniendo un gel de peróxido de hidrógeno al $4 \%$. Veinte incisivos bovinos intactos fueron asignados aleatoriamente a dos grupos $(n-10)$ almacenados en G1 - agua destilada y G2- saliva artificial. Se utilizó una escala analítica electrónica (.000 gramos) para determinar la variación de la masa de esmalte antes y después de los procedimientos de blanqueamiento en los siguientes tiempos de evaluación: T0) antes de los procedimientos blanqueadores; T1) 14 días de tratamiento, según las instrucciones del fabricante; T2) 21 días de tratamiento, $50 \%$ más allá del tiempo indicado por el fabricante; y T3) 28 días de tratamiento, $100 \%$ más allá del tiempo indicado por el fabricante. La media más alta se observó en T2/G2 $(0,3259 \mathrm{~g})$ y la más baja en T2/G1 (0,3265 g). Los especímenes almacenados en agua destilada (G1) mostraron una reducción de masa del $6 \%$ cuando se comparó T0 $(0,3277$ g) con T3 $(0,3277 \mathrm{~g})$. Por otro lado, los dientes almacenados en saliva artificial mostraron un aumento significativo de masa del $19 \%$ cuando se comparó T0 $(0,3521$ g) con T3 $(0,3528 \mathrm{~g})$. La terapia de blanqueamiemto prolongado con calcio conteniendo un gel de peróxido de hidrógeno al $4 \%$ condujo a una reducción masiva cuando se utilizó agua como medio de almacenamiento, mientras que los dientes almacenados en saliva artificial mostraron un aumento en la masa, probablemente debido a las propiedades remineralizadoras de la saliva artificial.

PALABRAS CLAVE: blanqueamiento dental, esmalte dental, peróxidos, in vitro.

\section{REFERENCES}

Abouassi, T.; Wolkewitz, M. \& Hahn, P. Effect of carbamide peroxide and hydrogen peroxide on enamel surface: an in vitro study. Clin. Oral Investig., 15(5):673-80, 2011.

Aka, B. \& Celik, E. U. Evaluation of the efficacy and color stability of two different at-home bleaching systems on teeth of different shades: a randomized controlled clinical trial. J. Esthet. Restor. Dent., 29(5):325-338, 2017.

Alexandrino, L.; Gomes, Y.; Alves, E.; Costi, H.; Rogez, H. \& Silva C. Effects of a bleaching agent with calcium on bovine enamel. Eur. J. Dent., 8(3):320-5, 2014.

Almeida, A. C. P.; Barros, K. S. B.; Ribeiro, M. E. S.; Baia, J. C. P.; Souza-Junior, M. H. S. \& Loretto, S. C. Influence of different time intervals among the in-office bleaching sessions on the tooth enamel mass variation. J. Health Sci., 21(4):342-7, 2019.

Alqahtani, M. Q. Tooth-bleaching procedures and their controversial effects: A literature review. Saudi Dent. J., 26(2):33-46, 2014.

Baia, J. C. P.; Oliveira, R. P.; Ribeiro, M. E. S.; Lima, R. R.; Loretto, S. C. \& Souza-Junior, M. H. S. Influence of prolonged dental bleaching on the adhesive bond strength to enamel surfaces. Int. J. Dent., (14):1-9, 2020.

Borges, A. B.; Zanatta, R. F.; Barros, A.C. S.M.; Silva, L. C.; Pucci, R. S. \& Torres, C. R. G. Effect of hydrogen peroxide concentration on enamel color and microhardness. Oper. Dent., 40(1):96-101, 2015.

Cakir, F. Y.; Korkmaz, Y.; Firat, E.; Oztas, S. S. \& Gurgan, S. Chemical analysis of enamel and dentin following the application of three different at-home bleaching systems. Oper. Dent., 36(5):529-36, 2011.

Cavalli, V.; Rodrigues, L. K.; Paes-Leme, A. F.; Silva, L. E.; Martin, A. A.; Berger, S. B. \& Giannini, M. Effects of the addition of fluoride and calcium to low-concentrated carbamide peroxide agents on the enamel surface and subsurface. Photomed. Laser Surg., 29(5):319-25, 2011.

Chen, H. P.; Chang, C. H.; Liu, J. K.; Chuang, S. F. \& Yang, J. Y. Effect of fluoride containing bleaching agents on enamel surface properties. J. Dent., 36(9):718-25, 2008.

Fjeld, M. \& Øgaard, B. Scanning electron microscopic evaluation of enamel surfaces exposed to 3 orthodontic bonding systems. Am. J. Orthod. Dentofacial Orthop., 130(5):575-81, 2006.

Franklin, S.; Masih, S. \& Thomas, A. M. An in-vitro assessment of erosive potential of a calcium-fortified fruit juice. Eur. Arch. Paediatr. Dent., 15(6):407-11, 2014.

Grobler, S. R.; Majeed, A. \& Moola, M. H. Effect of various toothwhitening products on enamel microhardness. S. A. D. J., 64(10):474-9, 2009.

Heshmat, H.; Ganjkar, M. H.; Miri, Y. \& Fard, M. J. K. The effect of two remineralizing agents and natural saliva on bleached enamel hardness. Dent. Res. J. (Isfahan), 13(1):52-7, 2016.

Ionta, F. Q.; Mendonca, F. L.; Oliveira, G. C. O.; Alencar, C. R. B.; Honório, H. M.; Magalhães, A. C. \& Rios, D. In vitro assessment of artificial saliva formulations on initial enamel erosion remineralization. J. Dent. 42(2):175-9, 2014.

Kwon, S. R. \& Wertz, P. W. Review of the mechanism of tooth whitening. J. Esthet. Restor. Dent., 27(5):240-57, 2015.

Mahringer, C.; Fureder, M.; Kastner, M.; Ebner, A.; Hinterdorfer, P.; Vitkov, L.; Hannig, M.; Kienberger, F. \& Schilcher, K. Examination of native and carbamide peroxide-bleached human tooth enamel by atomic force microscopy. Ultrastruct. Pathol., 33(5):189-96, 2009.

Mehl, C. J.; Harder, S.; Kern, M. \& Wolfart, S. Patients' and dentists perception of dental appearance. Clin. Oral Investig., 15(2):1939, 2011. 
SANTOS, H. S. B.; RIBEIRO, M. E. S.; DA SILVA, T. S. P.; LIMA, R. R.; LORETTO, S. C. \& DA SILVA E SOUZA JÚNIOR, M. H. Evaluation of dental enamel mass in prolonged supervised dental bleaching protocol with calcium-containing gel. Int. J. Odontostomat., 15(2):415-4120, 2021.

Meireles, S. S.; Fontes, S. T.; Coimbra, L. A. A.; Bona, Á. D. \& Demarco, F. F. Effectiveness of different carbamide peroxide concentrations used for tooth bleaching: an in vitro study. J. Appl. Oral Sci., 20(2):186-91, 2012.

Mondelli, R. F. L.; Gabriel, T. R. C. G.; Rizzante, F. A. P.; Magalhães, A. C.; Bombonatti, J. F. S. \& Ishikiriama, S. K. Do different bleaching protocols affect the enamel microhardness? Eur. J. Dent., 9(1):25-30, 2015.

Peruchi, L. D.; Sartori, N.; Lopes, G. C.; Ballarin, A.; Ambrosi, C. \& Bernardon, J. K. Clinical evaluation of $4 \%$ hydrogen peroxide bleaching in mandibular teeth. R. S. B. O., 8(4):398-403, 2011.

Pizani, A. M. A.; Tholt, B.; Paciornik, S.; Dias, K. R. H. C.; Albuquerque, P. P. A. C. \& Queiroz, C. S. Dental bleaching agents with calcium and their effects on enamel microhardness and morphology. Braz. J. Oral Sci., 14(2):154-8, 2015.

Ren, Y. F.; Amin, A. \& Malmstrom, H. Effects of tooth whitening and orange juice on surface properties of dental enamel. J. Dent., 37(6):424-31, 2009.

Ribeiro, E. S. R.; Santos, H. S. B.; Baia, J. C.P .; Oliveira, R. P.; Souza-Junior, M. H. S \& Loretto, S. C. Influence of prolonged tooth bleaching on enamel mass variation. Int. J. Odontostomat., 13(3):305-9, 2019.

Santos, G. C.; Baia, J. C.; Ribeiro, M. E.; Lima, R. R.; Souza-Junior, M. H. S \& Loretto, S. C. Influence of prolonged bleaching with 4 $\%$ hydrogen peroxide containing calcium and different storage times on the bond strength to enamel. J. Contemp. Dent. Pract., 20(2):216-20, 2019.

Sasaki, R. T.; Catelan, A.; Bertoldo, E. S.; Venâncio, P. C.; Groppo, F. C.; Ambrosano, G. M.; Marchi, G. M.; Lima, D. A. \& Aguiar, F. $\mathrm{H}$. Effect of $7.5 \%$ hydrogen peroxide containing remineralizing agents on hardness, color change, roughness and micromorphology of human enamel. Am. J. Dent., 28(5):261-7, 2015.

Souza, R. O. A.; Lombardo, G. H. L.; Pereira, S. M. B.; Zamboni, S. C.; Valera, M. C.; Araujo, M. A. M. \& Özcan, M. Analysis of tooth enamel after excessive bleaching: a study using scanning electron microscopy and energy dispersive $x$-ray spectroscopy. Int. J. Prosthodont., 23(1):29-32, 2010.

Spear, F. M. \& Kokich, V. G. A Multidisciplinary approach to esthetic dentistry. Dent. Clin. North Am., 51(2):487-505, 2007.

Sulieman, M. An overview of bleaching techniques: 2 . Night guard vital bleaching and non-vital bleaching. Dent. Update, 32(1):3946, 2005.

Sun, L.; Liang, S.; Sa, Y.; Wang, Z.; Ma, X.; Jiang, T. \& Wang, Y. Surface alteration of human tooth enamel subjected to acidic and neutral $30 \%$ hydrogen peroxide. J. Dent., 39(10):686-92, 2011.

Vilhena, K. F. B.; Nogueira, B. C. L.; Fagundes, N. C. F.; Loretto, S. C.; Angelica, R. S.; Lima, R. R. \& Souza-Junior, M. H. S. Dental enamel bleached for a prolonged and excessive time: Morphological changes. PLoS One, 14(4):e0214948, 2019.

$\mathrm{Xu}, \mathrm{B}$.; Li, Q. \& Wang, Y. Effects of $\mathrm{pH}$ values of hydrogen peroxide bleaching agents on enamel surface properties. Oper. Dent., 36(5):554-62, 2011.

Zimmer, S.; Kirchner, G.; Bizhang, M. \& Benedix, M. Influence of various acidic beverages on tooth erosion: Evaluation by a new method. PLoS One, 10(6):e0129462, 2015.
Corresponding author:

Mara Eliane Soares Ribeiro.

Rodovia Mário Covas, 1835

Coqueiro

CEP: $66650-000$

Belém/PA

BRAZIL

E-mail: maribe036@gmail.com 